\title{
Imino-quinolyl palladium(II) and platinum(II) complexes: synthesis, characterization, molecular structures and cytotoxic effect
}

William M. Motswainyana, Martin O. Onani, Abram M. Madiehe, Morounke Saibu, Jeroen Jacobs, Luc van Meervelt

\begin{abstract}
Imino-quinolyl ligands L1-L5 were synthesized by condensation reactions and obtained in good yields. Reactions of the ligands with either $\mathrm{PdCl}_{2}$ (cod) or $\mathrm{K}_{2}\left[\mathrm{PtCl}_{4}\right]$ gave the corresponding palladium(II) and platinum(II) complexes 1-10 also in good yields. All the compounds were characterized by elemental analysis, IR, ${ }^{1} \mathrm{H}$ and ${ }^{13} \mathrm{C}$ NMR spectroscopy. X-ray crystallography was used to confirm the structures of these compounds. Molecular structures of $\mathbf{3}$ and $\mathbf{5}$ showed that the ligands coordinate to the metal centre through the two nitrogen atoms, generating a distorted square planar geometry around the palladium atom. The new complexes exhibited remarkable cytotoxic activities against MCF-7 and HT-29 cancer cell lines.
\end{abstract}

Keywords: Imino-quinolyl; Palladium; Platinum; Molecular structures; Cancer; Cytotoxicity

\section{1.o Introduction}

Transition metal complexes containing nitrogen-donor ligands continue to be the subject of intense biological evaluations as the search for less toxic and more selective anticancer drugs continues [1]. The subtlety with which the ligands control the reactivity of transition metal ions and the reciprocal effects that the metal ions have on the properties of ligands are some of the interesting dimensions being explored in the search for suitable ligands in metallo-drugs [2]. Existing examples are seen in the use of pyridine based platinum(II) complexes as mimics of cisplatin, because the pyridine ligand gives rise to square planar complexes which are structurally similar to cisplatin [3]. One important aspect relating to planar ligands is that their complexes reduce the rate of deactivation by thiol containing groups without interfering with DNA binding [3]. The use of chelating, bidentate ligands has also been viewed as important in preventing trans-labilization and undesired displacement of the ligands by sulphur and nitrogen donors in biomolecules [4].

Recent research has shown that for a palladium drug to be developed, it should be stabilized by a chelate or a strongly coordinated, bulky monodentate nitrogen ligand and a suitable leaving group [5]. Reports have also demonstrated that varying the aniline functionality allows the design of compounds with a wide range of physical and chemical properties that may provide desired steric congestion around the coordinated metal atom [6]. The steric hindrance is favourable for this type of work because it prevents axial approach to the metal atom, therefore inhibiting the 
formation of a five-coordinate intermediate that would otherwise lead to a ligand substitution. This phenomenon permits high selectivity in binding to DNA [6]. It is against this background that we report the synthesis and characterization of sterically congested palladium(II) and platinum(II) complexes derived from quinoline imine bearing substituted aniline moiety. The new complexes were investigated in vitro for their potential to exert cytotoxicity on MCF-7 and HT-29 cancer cells and the results are herein discussed.

\subsection{Experimental}

\subsection{Materials and methods}

All reactions were carried out under nitrogen atmosphere using a dual vacuum/nitrogen line and standard Schlenk techniques unless stated otherwise. Solvents were dried and purified by heating at reflux under nitrogen in the presence of a suitable drying agent. All the reagents and starting materials were purchased from Sigma-Aldrich and were used without any further purification. The palladium(II) precursor $\mathrm{PdCl}_{2}$ (cod) was prepared following literature method [7]. The ${ }^{1}$ H NMR experiments were performed on a Varian XR200 MHz spectrometer. IR spectra in solution were recorded with a Perkin-Elmer Spectrum 100 Series FT-IR instrument using nujol mulls on $\mathrm{NaCl}$ plates. Elemental analysis was performed on Server 1112 Series Elemental Analyzer. X-ray diffraction data for the compound was collected on a Agilent SuperNova diffractometer using mirror-monochromated MoK $\alpha$ radiation $(\lambda=0.71073 \AA)$. The crystal structures were solved by direct methods using SHELX [8] and refined by full-matrix least-squares methods based on $F^{2}$ [8] using SHELX [8] and using the graphics program OLEX2 [9].

\subsection{Synthesis of the ligands}

\subsubsection{2-phenyliminomethylquinoline (L1)}

To a solution of 2-quinolinecarboxaldehyde (0.3830 g, $2.44 \mathrm{mmol}$ ) in $\mathrm{CH}_{2} \mathrm{Cl}_{2}$ (10 ml) was added aniline $(0.2269 \mathrm{~g}, 2.44 \mathrm{mmol})$ dropwise. The reaction was stirred at room temperature for $10 \mathrm{hrs}$, and a crude product was obtained after evaporation of the solvent. The product was washed with water $(10 \mathrm{ml})$ and the organic material extracted with $\mathrm{CH}_{2} \mathrm{Cl}_{2}(2 \times 10 \mathrm{ml})$, and dried over anhydrous magnesium sulphate. Reddish brown oil was obtained upon evaporation of the solvent. Yield: $0.5214 \mathrm{~g}$ (92\%); IR (nujol $\left.\mathrm{cm}^{-1}\right) ; v(\mathrm{C}=\mathrm{N}$ imine) $1626, v(\mathrm{C}=\mathrm{N}$ quinolyl) $1598, v(\mathrm{C}=\mathrm{C}$ quinolyl) 1560, $\left(\mathrm{C}=\mathrm{C}\right.$ phenyl) $1503 ;{ }^{1} \mathrm{H}$ NMR (200 MHz, $\mathrm{CDCl}_{3}$ ): $\delta 8.79$ (s, $1 \mathrm{H}$, quinolyl); 8.37 (d, $1 \mathrm{H}, J=8.4$, quinolyl); 8.27 (dd, $1 \mathrm{H}, J=8.2$, quinolyl); $7.93-7.10$ (m, $4 \mathrm{H}$, quinolyl and imine); $6.79-6.66\left(\mathrm{~m}, 5 \mathrm{H}\right.$, phenyl); ${ }^{13} \mathrm{C} \mathrm{NMR}\left(50 \mathrm{MHz}, \mathrm{CDCl}_{3}\right) \delta$ $154.84,115.07,136.64,129.92,147.97,127.72,121.23,128.90,127.75,160.89$ (imine), 150.81, 118.65, 129.71, 126.95, 129.25, 118.53; Anal. Calcd for $\mathrm{C}_{16} \mathrm{H}_{12} \mathrm{~N}_{2}: \mathrm{C}, 82.73 ; \mathrm{H}$, 5.21 ; N, 12.06; Found: C, 82.95; H, 4.91; N, 12.32

\subsubsection{2-(2-methylphenyl)iminomethylquinoline (L2)}

The ligand was synthesized according to the procedure described for L1 using 2quinolinecarboxaldehyde $(0.3266 \mathrm{~g}, 2.08 \mathrm{mmol})$ and 2-methylaniline $(0.2227 \mathrm{~g}, 2.08$ 
mmol). Reddish brown oil was obtained. Yield: $0.4713 \mathrm{~g}$ (92\%); IR (nujol $\mathrm{cm}^{-1}$ ); $v(\mathrm{C}=\mathrm{N}$ imine $) 1625, v(\mathrm{C}=\mathrm{N}$ quinolyl) $1595, v(\mathrm{C}=\mathrm{C}$ quinolyl) $1560,(\mathrm{C}=\mathrm{C}$ phenyl) 1504 ; ${ }^{1} \mathrm{H}$ NMR (200 $\mathrm{MHz}, \mathrm{CDCl}_{3}$ ): $\delta 8.68$ (s, $1 \mathrm{H}$, quinolyl); 8.38 (d, $1 \mathrm{H}, J=8.8$, quinolyl); 8.19 (dd, $1 \mathrm{H}, J=8.4$, quinolyl); $7.88-6.98$ (m, 4H, quinolyl and imine); $6.72-6.63$ (m, 5H, phenyl); 2.42 (s, 3H, Me); ${ }^{13} \mathrm{C} \mathrm{NMR} \mathrm{(50} \mathrm{MHz,} \mathrm{CDCl}_{3}$ ) $\delta$ 155.08, 114.89, 136.58, 132.59, 147.93, 127.65, 126.63, 128.88, 127.74, 160.01 (imine), 149.81, 118.65, 130.43, 126.92, 129.88, 117.48, 17.88; Anal. Calcd for $\mathrm{C}_{17} \mathrm{H}_{14} \mathrm{~N}_{2}$ : C, 82.90; H, 5.73; N, 11.37; Found: C, 83.14; H, 6.02; N, 11.55

\subsubsection{2-(2,6-dimethylphenyl)iminomethylquinoline (L3)}

The ligand was synthesized according to the procedure described for L1 using 2quinolinecarboxaldehyde ( $0.2913 \mathrm{~g}, 1.85 \mathrm{mmol})$ and 2,6-dimethylaniline (0.2246 g, $1.85 \mathrm{mmol}$ ). Reddish brown oil was obtained. Yield: $0.4527 \mathrm{~g}$ (94\%); IR (nujol $\mathrm{cm}^{-1}$ ); $v(\mathrm{C}=\mathrm{N}$ imine $) 1639, v(\mathrm{C}=\mathrm{N}$ quinolyl) $1595, v(\mathrm{C}=\mathrm{C}$ quinolyl) 1562, (C=C phenyl) 1503; ${ }^{1} \mathrm{H}$ NMR (200 MHz, $\mathrm{CDCl}_{3}$ ): $\delta 8.50$ (s, $1 \mathrm{H}$, quinolyl); 8.42 (d, $1 \mathrm{H}, J=8.4$, quinolyl); 8.22 (dd, $1 \mathrm{H}, J=8.0$, quinolyl); $7.91-6.92$ (m, $4 \mathrm{H}$, quinolyl and imine); $6.67-6.63$ (m, $5 \mathrm{H}$, phenyl); 2.19 (s, 6H, Me); ${ }^{13 \mathrm{C} \mathrm{NMR}}\left(50 \mathrm{MHz}, \mathrm{CDCl}_{3}\right.$ ) $\delta$ 154.62, 117.99, 136.71, 129.95, 145.53, 127.78, 124.15, 128.22, 128.14, 163.84 (imine), 150.30, 121.68, 129.77, 126.79, 129.05, 118.18, 18.31, 17.59; Anal. Calcd for $\mathrm{C}_{18} \mathrm{H}_{16} \mathrm{~N}_{2}$ : C, 83.04; H, 6.19; N, 10.76; Found: C, 83.27; H, 6.45; N, 11.01

\subsubsection{2-(2,6-diethylphenyl)iminomethylquinoline (L4)}

The ligand was synthesized according to the procedure described for L1 using 2quinolinecarboxaldehyde (0.3130 g, $1.99 \mathrm{mmol}$ ) and 2,6-diethylaniline (0.2972 g, $1.99 \mathrm{mmol}$ ). Reddish brown oil was obtained [10]. Yield: $0.5509 \mathrm{~g}$ (96\%); IR (nujol $\left.\mathrm{cm}^{-1}\right) ; v(\mathrm{C}=\mathrm{N}$ imine $) 1641, v(\mathrm{C}=\mathrm{N}$ quinoly $) 1596, v(\mathrm{C}=\mathrm{C}$ quinolyl) 1563 , $(\mathrm{C}=\mathrm{C}$ phenyl) 1504; ${ }^{1} \mathrm{H}$ NMR (200 $\mathrm{MHz}, \mathrm{CDCl}_{3}$ ): $\delta 8.47$ (s, $1 \mathrm{H}$, quinolyl); $8.39(\mathrm{~d}, 1 \mathrm{H}, J=8.4$, quinolyl); 8.21 (dd, $1 \mathrm{H}, J=8.4$, quinolyl); $7.91-6.94$ (m, $4 \mathrm{H}$, quinolyl and imine); $6.76-6.69$ (m, 5 H, phenyl); 2.52 (dd, $4 \mathrm{H}, \mathrm{Me}) ; 1.57-1.09$ (m, 6H, Me); ${ }^{3} \mathrm{C}$ NMR (50 MHz, $\mathrm{CDCl}_{3}$ ) $\delta 154.55,118.16,136.70,132.62,147.92,127.73,125.96,129.02$, 127.73, 163.43 (imine), 149.54, 124.32, 129.89, 126.25, 129.76, 118.26, 24.65, 24.23, 14.53, 12.97; Anal. Calcd for $\mathrm{C}_{20} \mathrm{H}_{20} \mathrm{~N}_{2}$ : C, 83.30; H, 6.99; N, 9.71; Found: C, 83.54; H, 6.78; N, 9.99

\subsubsection{2- (2,6-dïsopropylphenyl) iminomethylquinoline (L5)}

The ligand was synthesized according to the procedure described for L1 using 2quinolinecarboxaldehyde $(0.3318 \mathrm{~g}, 2.11 \mathrm{mmol})$ and 2,6-diisopropylaniline ( $0.3743 \mathrm{~g}$, $2.11 \mathrm{mmol}$ ). Reddish brown oil was obtained. Yield: $0.6276 \mathrm{~g}$ (94\%); IR (nujol $\mathrm{cm}^{-1}$ ); $v(\mathrm{C}=\mathrm{N}$ imine $) 1642, v(\mathrm{C}=\mathrm{N}$ quinolyl) $1595, v(\mathrm{C}=\mathrm{C}$ quinolyl) 1562, $(\mathrm{C}=\mathrm{C}$ phenyl) 1504; ${ }^{1} \mathrm{H}$ NMR (200 $\mathrm{MHz}, \mathrm{CDCl}_{3}$ ): $\delta 8.45$ (s, $1 \mathrm{H}$, quinolyl); 8.40 (d, $1 \mathrm{H}, J=8.2$, quinolyl); 8.21 (dd, $1 \mathrm{H}, J=8.0$, quinolyl); $7.91-7.04$ (m, 4H, quinolyl and imine); $6.79-6.68$ (m, $5 \mathrm{H}$, phenyl); $3.05-2.87$ (m, 2H, Me); 1.22 (dd, $12 \mathrm{H}, J=1.2, \mathrm{Me}) ;{ }^{13} \mathrm{C}$ NMR (5O $\mathrm{MHz}, \mathrm{CDCl}_{3}$ ) $\delta 154.57,118.33,136.78,132.48,148.03,124.56,129.86,129.11,163.44$ 
(imine), 148.44, 127.81, 129.98, 23.08, 28.02, 23.44, 22.47; Anal. Calcd for $\mathrm{C}_{22} \mathrm{H}_{24} \mathrm{~N}_{2}$ : C, 83.50; H, 7.64; N, 8.85; Found: C, 83.25; H, 7.92; N, 8.59

\subsection{Synthesis of palladium(II) complexes}

2.3.1 Dichloro-[2-(phenyliminomethyl)quinoline]palladium(II) (1)

To a solution of $\mathbf{L 1}(0.0748 \mathrm{~g}, 0.322 \mathrm{mmol})$ in dry $\mathrm{CH}_{2} \mathrm{Cl}_{2}(10 \mathrm{ml})$ was added dropwise a solution of $\mathrm{PdCl}_{2}$ (cod) (0.0925 g, $0.324 \mathrm{mmol}$ ) in $\mathrm{CH}_{2} \mathrm{Cl}_{2}(5 \mathrm{ml})$. The yellow solution was refluxed for $4 \mathrm{hrs}$, resulting in the formation of yellow precipitate. The precipitate was filtered and washed with $\mathrm{Et}_{2} \mathrm{O}(2 \times 10 \mathrm{ml})$ to obtain a pure yellow solid which formed single crystals suitable for X-ray crystallography when it was recrystallized from a mixture of $\mathrm{CH}_{2} \mathrm{Cl}_{2}: \mathrm{C}_{6} \mathrm{H}_{14}$ solution [11]. Yield: 0.1082 $\mathrm{g}(82 \%)$; IR (nujol $\left.\mathrm{cm}^{-1}\right) ; v(\mathrm{C}=\mathrm{N}$ imine) $1599, v(\mathrm{C}=\mathrm{N}$ quinolyl) $1588, v(\mathrm{C}=\mathrm{C}$ quinolyl $)$ 1572, (C=C phenyl) 1511; ${ }^{1} \mathrm{H}$ NMR (200 MHz, DMSO): $\delta 8.50(\mathrm{~d}, 1 \mathrm{H}, J=8.4$, quinolyl); 8.30 (d, $1 \mathrm{H}, J=8.2$, quinolyl); $8.11-7.28$ (m, $4 \mathrm{H}$, quinolyl and imine); 8.77 (d, $1 \mathrm{H}, J=8.0$, quinolyl); $6.87-6.70$ (m, $5 \mathrm{H}$, phenyl); Anal. Calcd for $\mathrm{C}_{16} \mathrm{H}_{12} \mathrm{Cl}_{2} \mathrm{~N}_{2}$ Pd: C, 46.92; H, 2.95; N, 6.84; Found: C, 47.20; H, 3.11; N, 6.99

\subsubsection{Dichloro-[2-(2-methylphenyl)iminomethylquinoline]palladium(II) (2)}

The compound was synthesized according to the procedure described for $\mathbf{1}$ using $\mathbf{L 2}$ (0.0634 g, $0.257 \mathrm{mmol})$ and $\mathrm{PdCl}_{2}$ (cod) (0.0744 g, $\left.0.257 \mathrm{mmol}\right)$. A yellow solid was obtained. Yield: $0.0969 \mathrm{~g}$ (89\%); IR (nujol $\left.\mathrm{cm}^{-1}\right) ; \mathrm{v}(\mathrm{C}=\mathrm{N}$ imine) 1599, $\mathrm{v}(\mathrm{C}=\mathrm{N}$ quinolyl) $1589, v\left(\mathrm{C}=\mathrm{C}\right.$ quinolyl) $1561,\left(\mathrm{C}=\mathrm{C}\right.$ phenyl) 1500 ; ${ }^{1} \mathrm{H}$ NMR $(200 \mathrm{MHz}$, DMSO): $\delta 8.46$ (d, $1 \mathrm{H}, J=8.2$, quinolyl); 8.36 (d, $1 \mathrm{H}, J=8.2$, quinolyl); $8.16-7.04$ (m, 4H, quinolyl and imine); $8.76(\mathrm{~d}, 1 \mathrm{H}, J=8.8$, quinolyl); $6.85-6.68(\mathrm{~m}, 5 \mathrm{H}$, phenyl); Anal. Calcd for $\mathrm{C}_{17} \mathrm{H}_{14} \mathrm{Cl}_{2} \mathrm{~N}_{2}$ Pd: C, 48.20; H, 3.33; N, 6.61; Found: C, 48.48; $\mathrm{H}, 3.17$; $\mathrm{N}, 6.52$

\subsubsection{Dichloro-[2-(2,6-dimethylphenyl)iminomethylquinoline]palladium(II) (3)}

The compound was synthesized according to the procedure described for $\mathbf{1}$ using $\mathbf{L 3}$ (0.0557 g, $0.214 \mathrm{mmol})$ and $\mathrm{PdCl}_{2}(\mathrm{cod})(0.0623 \mathrm{~g}, 0.218 \mathrm{mmol})$. A yellow solid was obtained. Suitable crystals for X-ray crystallography were grown by slow evaporation of $\mathrm{CH}_{3} \mathrm{CN}$ solution of the complex. Yield: $0.0805 \mathrm{~g}(86 \%) \mathrm{IR}$ (nujol $\left.\mathrm{cm}^{-1}\right) ; \mathrm{v}(\mathrm{C}=\mathrm{N}$ imine) $1599, v\left(\mathrm{C}=\mathrm{N}\right.$ quinolyl) $1585, \mathrm{v}\left(\mathrm{C}=\mathrm{C}\right.$ quinolyl) $1565,\left(\mathrm{C}=\mathrm{C}\right.$ phenyl) $1510 ;{ }^{1} \mathrm{H}$ NMR (200 MHz, DMSO): $\delta 8.42$ (d, $1 \mathrm{H}, J=8.2$, quinolyl); 8.34 (d, $1 \mathrm{H}, J=8.2$, quinolyl); $8.27-6.96(\mathrm{~m}, 4 \mathrm{H}$, quinolyl and imine); 8.72 (d, $1 \mathrm{H}, J=7.8$, quinolyl); $6.82-6.73$ (m, $5 \mathrm{H}$, phenyl); Anal. Calcd for $\mathrm{C}_{18} \mathrm{H}_{16} \mathrm{Cl}_{2} \mathrm{~N}_{2}$ Pd: C, 49.40; H, 3.68; N, 6.40; Found: C, 49.16; H, 3.88; N, 6.22

\subsubsection{Dichloro-[2-(2,6-diethylphenyl)iminomethylquinoline]palladium(II) (4)}

The compound was synthesized according to the procedure described for $\mathbf{1}$ using $\mathbf{L} \mathbf{4}$ (0.0640 g, $0.222 \mathrm{mmol}$ ) and $\mathrm{PdCl}_{2}$ (cod) (0.0650 g, $0.228 \mathrm{mmol}$ ). A yellow solid was obtained. Suitable crystals for $\mathrm{X}$-ray crystallography were grown by slow evaporation of $\mathrm{CH}_{3} \mathrm{CN}$ solution of the complex [1o]. Yield: $0.0848 \mathrm{~g}(82 \%) \mathrm{IR}$ (nujol $\left.\mathrm{cm}^{-1}\right) ; \mathrm{v}(\mathrm{C}=\mathrm{N}$ imine) 1602, $v\left(\mathrm{C}=\mathrm{N}\right.$ quinolyl) $1584, \mathrm{v}\left(\mathrm{C}=\mathrm{C}\right.$ quinolyl) $1563,\left(\mathrm{C}=\mathrm{C}\right.$ phenyl) $1506 ;{ }^{1} \mathrm{H}$ 
NMR (200 MHz, DMSO): $\delta 8.42$ (d, $1 \mathrm{H}, J=8.4$, quinolyl); 8.36 (d, $1 \mathrm{H}, J=8.2$, quinolyl); $8.23-6.96(\mathrm{~m}, 4 \mathrm{H}$, quinolyl and imine); 8.77 (d, $1 \mathrm{H}, J=7.4$, quinolyl); $6.88-6.78$ (m, 5H, phenyl); Anal. Calcd for $\mathrm{C}_{20} \mathrm{H}_{20} \mathrm{Cl}_{2} \mathrm{~N}_{2} \mathrm{Pd}$ : C, 51.58; H, 4.33; N, 6.02; Found: C, 51.89; H, 4.18; N, 5.83

\subsubsection{Dichloro-[2-(2,6-diisopropylphenyl)iminomethylquinoline]palladium(II) (5)}

The compound was synthesized according to the procedure described for $\mathbf{1}$ using $\mathbf{L} 5$ (0.0645 g, $0.204 \mathrm{mmol}$ ) and $\mathrm{PdCl}_{2}$ (cod) (0.0598, $\left.0.209 \mathrm{mmol}\right)$. A yellow solid was obtained. Suitable crystals for X-ray crystallography were grown by slow diffusion of $\mathrm{C}_{6} \mathrm{H}_{14}$ into a solution of the complex in $\mathrm{CH}_{2} \mathrm{Cl}_{2}$.Yield: $0.0856 \mathrm{~g}$ (85\%) IR (nujol cm${ }^{-1}$ ); $v(\mathrm{C}=\mathrm{N}$ imine $)$ 1606, $v(\mathrm{C}=\mathrm{N}$ quinolyl) $1589, \mathrm{v}(\mathrm{C}=\mathrm{C}$ quinolyl) $1562,(\mathrm{C}=\mathrm{C}$ phenyl) 1514 ; ${ }^{1} \mathrm{H}$ NMR (200 MHz, DMSO): $\delta 8.44$ (d, $1 \mathrm{H}, J=8.4$, quinolyl); 8.35 (d, $1 \mathrm{H}, J=8.0$, quinolyl); $8.22-6.98$ (m, $4 \mathrm{H}$, quinolyl and imine); 8.78 (d, $1 \mathrm{H}, J=7.6$, quinolyl); $6.78-6.71$ (m, $5 \mathrm{H}$, phenyl); Anal. Calcd for $\mathrm{C}_{22} \mathrm{H}_{24} \mathrm{Cl}_{2} \mathrm{~N}_{2} \mathrm{Pd}$ : C, 53.51; H, 4.90; N, 5.67; Found: C, 53.28; H, 4.72; N, 5.93

\subsection{Synthesis of platinum(II) complexes}

2.4.1 Dichloro-[2-(phenyliminomethyl)quinoline]platinum(II) (6)

To a solution of $\mathbf{L 1}(0.0627 \mathrm{~g}, 0.270 \mathrm{mmol})$ in dry $\mathrm{MeOH}(10 \mathrm{ml})$ was added dropwise an aqueous solution of $\mathrm{K}_{2}\left[\mathrm{PtCl}_{4}\right]$ (0.1115 g, $\left.0.269 \mathrm{mmol}\right)(5 \mathrm{ml})$. The reaction was stirred at room temperature for $15 \mathrm{hrs}$, resulting in the formation of an orange precipitate. The precipitate was filtered and washed with $\mathrm{Et}_{2} \mathrm{O}(2 \mathrm{x} 10 \mathrm{ml})$ to obtain a pure orange solid. Yield: $0.1019 \mathrm{~g}$ (76\%); IR (nujol $\left.\mathrm{cm}^{-1}\right) \mathrm{v}(\mathrm{C}=\mathrm{N}$ imine) 1610, $\mathrm{v}\left(\mathrm{C}=\mathrm{N}\right.$ quinolyl) 1586, $\mathrm{v}\left(\mathrm{C}=\mathrm{C}\right.$ quinolyl) $1560,\left(\mathrm{C}=\mathrm{C}\right.$ phenyl) $1510 ;{ }^{1} \mathrm{H} \mathrm{NMR}(200 \mathrm{MHz}$, DMSO): $\delta 8.62$ (d, $1 \mathrm{H}, J=9.2$, quinolyl ); 8.33 (d, $1 \mathrm{H}, J=8.8$, quinolyl); $8.12-7.03$ (m, 4H, quinolyl and imine); $8.71(\mathrm{~d}, 1 \mathrm{H}, J=8.4$, quinolyl); $6.89-6.59(\mathrm{~m}, 5 \mathrm{H}$, phenyl); Anal. Calcd for $\mathrm{C}_{16} \mathrm{H}_{12} \mathrm{Cl}_{2} \mathrm{~N}_{2}$ Pt: C, 38.57; H, 2.43; N, 5.62; Found: C, 38.72; H, 2.62; N, 5.76

\subsubsection{Dichloro-[2-(2-methylphenyl)iminomethylquinoline]platinum(II) (7)}

The compound was synthesized according to the procedure described for $\mathbf{6}$ using $\mathbf{L 2}$ (0.0679 g, $0.276 \mathrm{mmol}$ ) and $\mathrm{K}_{2}\left[\mathrm{PtCl}_{4}\right](0.1146 \mathrm{~g}, 0.276 \mathrm{mmol})$. An orange solid was obtained. Yield: $0.1060 \mathrm{~g}$ (75\%); IR (nujol $\left.\mathrm{cm}^{-1}\right) \mathrm{v}(\mathrm{C}=\mathrm{N}$ imine) 1612, $\mathrm{v}(\mathrm{C}=\mathrm{N}$ quinolyl) 1588, v(C=C quinolyl) 1557, (C=C phenyl) 1512; ${ }^{1} \mathrm{H}$ NMR (200 MHz, DMSO): $\delta 8.57$ (d, $1 \mathrm{H}, J=8.6$, quinolyl); 8.34 (d, $1 \mathrm{H}, J=8.0$, quinolyl); $8.25-7.17$ (m, $4 \mathrm{H}$, quinolyl and imine); 8.72 (d, $1 \mathrm{H}, J=8.4$, quinolyl); $6.79-6.58$ (m, $5 \mathrm{H}$, phenyl); Anal. Calcd for $\mathrm{C}_{17} \mathrm{H}_{14} \mathrm{Cl}_{2} \mathrm{~N}_{2}$ Pt: C, 39.86; H, 2.75; N, 5.47; Found: C, 40.08; H, 3.03; N, 5.33

\subsubsection{Dichloro-[2-(2,6-dimethylphenyl)iminomethylquinoline]platinum(II) (8)}

The compound was synthesized according to the procedure described for $\mathbf{6}$ using $\mathbf{L} \mathbf{3}$ (0.0643 g, $0.247 \mathrm{mmol})$ and $\mathrm{K}_{2}\left[\mathrm{PtCl}_{4}\right](0.1035 \mathrm{~g}, 0.249 \mathrm{mmol})$. An orange solid was obtained. Yield: $0.1014 \mathrm{~g}$ (78\%); IR (nujol $\left.\mathrm{cm}^{-1}\right) \mathrm{v}(\mathrm{C}=\mathrm{N}$ imine) $1607, \mathrm{v}(\mathrm{C}=\mathrm{N}$ quinolyl) 1589, v(C=C quinolyl) 1561, (C=C phenyl) 1513; ${ }^{1} \mathrm{H}$ NMR (200 MHz, DMSO): $\delta 8.44$ (d, $1 \mathrm{H}, J=8.0$, quinolyl); 8.32 (d, $1 \mathrm{H}, J=8.6$, quinolyl); $8.01-6.92$ (m, 4H, quinolyl 
and imine); 8.73 (d, $1 \mathrm{H}, J=8.4$, quinolyl); $6.78-6.59$ (m, $5 \mathrm{H}$, phenyl); Anal. Calcd for $\mathrm{C}_{18} \mathrm{H}_{16} \mathrm{Cl}_{2} \mathrm{~N}_{2} \mathrm{Pt}$ : C, 41.08; H, 3.06; N, 5.32; Found: C, 40.94; H, 2.77; N, 5.06

\subsubsection{Dichloro-[2-(2,6-diethylphenyl)iminomethylquinoline]platinum(II) (9)}

The compound was synthesized according to the procedure described for $\mathbf{6}$ using $\mathbf{L 4}$ (0.0728 g, $0.252 \mathrm{mmol})$ and $\mathrm{K}_{2}\left[\mathrm{PtCl}_{4}\right](0.1059 \mathrm{~g}, 0.255 \mathrm{mmol})$. An orange solid was obtained. Yield: $0.1034 \mathrm{~g}$ (74\%); IR (nujol cm $\left.{ }^{-1}\right) v(\mathrm{C}=\mathrm{N}$ imine) $1608, v(\mathrm{C}=\mathrm{N}$ quinolyl) 1587, v(C=C quinolyl) 1566, (C=C phenyl) $1516 ;{ }^{1} \mathrm{H}$ NMR (200 MHz, DMSO): $\delta 8.43$ (d, $1 \mathrm{H}, J=8.6$, quinolyl); 8.35 (d, $1 \mathrm{H}, J=8.2$, quinolyl); $8.19-6.89$ (m, $4 \mathrm{H}$, quinolyl and imine); 8.72 (d, $1 \mathrm{H}, J=8.2$, quinolyl); $6.76-6.56$ (m, $5 \mathrm{H}$, phenyl); Anal. Calcd for $\mathrm{C}_{20} \mathrm{H}_{20} \mathrm{Cl}_{2} \mathrm{~N}_{2}$ Pt: C, 43.33; H, 3.64; N, 5.05; Found: C, 43.09; H, 3.91; N, 5.22

\subsubsection{Dichloro-[2-(2,6-düsopropylphenyl)iminomethylquinoline]platinum(II) (10)} The compound was synthesized according to the procedure described for $\mathbf{6}$ using $\mathbf{L 5}$ (0.0472 g, $0.149 \mathrm{mmol})$ and $\mathrm{K}_{2}\left[\mathrm{PtCl}_{4}\right](0.0633 \mathrm{~g}, 0.152 \mathrm{mmol})$. An orange solid was obtained. Yield: $0.0651 \mathrm{~g}$ (75\%); IR (nujol $\left.\mathrm{cm}^{-1}\right) v(\mathrm{C}=\mathrm{N}$ imine) 1612, $v(\mathrm{C}=\mathrm{N}$ quinolyl) 1588, $v\left(\mathrm{C}=\mathrm{C}\right.$ quinolyl) 1564, (C=C phenyl) $1514 ;{ }^{1} \mathrm{H}$ NMR (200 MHz, DMSO): $\delta 8.42$ (d, $1 \mathrm{H}, J=8.0$, quinolyl); 8.37 (d, $1 \mathrm{H}, J=8.4$, quinolyl); $8.12-6.85$ (m, $4 \mathrm{H}$, quinolyl and imine); 8.75 (d, $1 \mathrm{H}, J=8.6$, quinolyl); $6.64-6.48$ (m, $5 \mathrm{H}$, phenyl); Anal. Calcd for $\mathrm{C}_{22} \mathrm{H}_{2} \mathrm{Cl}_{2} \mathrm{~N}_{2}$ Pt: C, 45.37; H, 4.15; N, 4.81; Found: C, 45.13; H, 4.35; N, 5.02

\subsection{Cytotoxicity determination}

\subsubsection{Cell culture}

The A2780 and MCF-7 cells were cultured in RPMI-1640 in $25 \mathrm{~cm}$ tissue culture flasks and were allowed to grow to $90 \%$ confluency in an incubator set at $37{ }^{\circ} \mathrm{C}$ containing $5 \% \mathrm{CO}_{2}$ atmospheric pressure, before they were trypsinized and cultured in 6 tissue culture plates. Stock and final concentrations of the complexes were prepared in the culture media.

\subsubsection{MTT assay}

The cells were plated in 96-well tissue plates at a density of $2.0 \times 10^{5}$ cells per well and treated with various concentrations of the palladium complexes that ranged from 100 to $10 \mu \mathrm{M}$ after which they were incubated for $24 \mathrm{hrs}$. Triplicate wells were established for each concentration. Just 5 hrs before the elapse of 24 hours, $10 \mu \mathrm{l}$ of $5 \mathrm{mg} / \mathrm{ml} \mathrm{MTT} \mathrm{solution} \mathrm{was} \mathrm{added} \mathrm{to} \mathrm{each} \mathrm{well} \mathrm{and} \mathrm{the} \mathrm{plates} \mathrm{were} \mathrm{further} \mathrm{incubated.}$ At the end of the incubation period, the media was removed from each well and replaced with $50 \mu \mathrm{l}$ of DMSO. The plates were shaken on a rotating shaker for 10 minutes before taking readings at $560 \mathrm{~nm}$ using a microplate reader.

\section{3.o Results and discussion}

\subsection{Synthesis of the ligands and metal complexes}

Imino-quinolyl ligands L1-L5 were successfully prepared by reacting 2quinolinecarboxaldehyde with substituted aniline and obtained in very good yields. Ligand L4 has been previously reported by our group, but it was not fully 
characterized [10]. The rest of the ligands have been reported by another research group [12] but they were independently prepared by us. The new corresponding palladium(II) and platinum(II) complexes 1-10 were subsequently prepared by equimolar reactions of the ligands with either $\mathrm{PdCl}_{2}$ (cod) or $\mathrm{K}_{2}\left[\mathrm{PtCl}_{4}\right]$ (Scheme 1). All the compounds were characterized using elemental analysis, IR, ${ }^{1} \mathrm{H}$ and ${ }^{13} \mathrm{C}$ NMR spectroscopy.
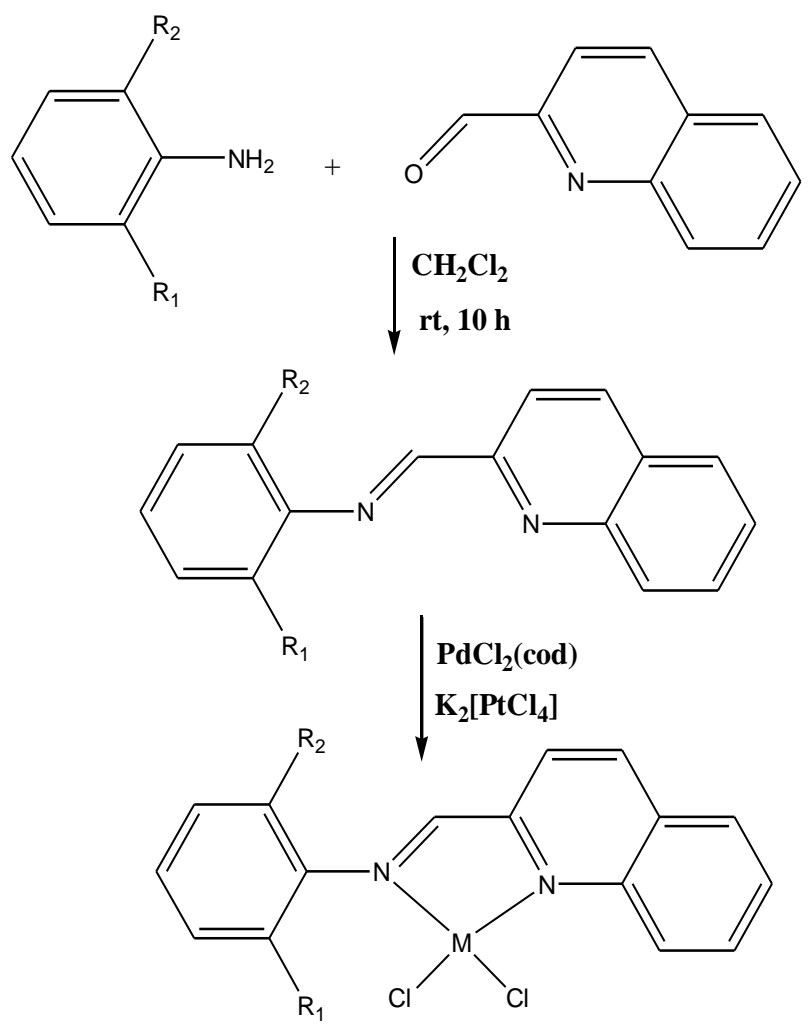

$$
\begin{aligned}
& \mathrm{R}_{1}=\mathrm{R}_{2}=\mathrm{H}, \mathrm{M}=\mathrm{Pd}(\mathbf{1}) ; \mathrm{M}=\operatorname{Pt}(\mathbf{6}) \\
& \mathrm{R}_{1}=\mathrm{Me}, \mathrm{R}_{2}=\mathrm{H}, \mathrm{M}=\operatorname{Pd}(\mathbf{2}) ; \mathrm{M}=\operatorname{Pt}(7) \\
& \mathrm{R}_{1}=\mathrm{R}_{2}=\mathrm{Me}, \mathrm{M}=\operatorname{Pd}(\mathbf{3}) ; \mathrm{M}=\operatorname{Pt}(\mathbf{8}) \\
& \mathrm{R}_{1}=\mathrm{R}_{2}=\mathrm{Et}, \mathrm{M}=\operatorname{Pd}(\mathbf{4}) ; \mathrm{M}=\operatorname{Pt}(\mathbf{9}) \\
& \mathrm{R}_{1}=\mathrm{R}_{2}=i \operatorname{Pr}, \mathrm{M}=\operatorname{Pd}(\mathbf{5}) ; \mathrm{M}=\operatorname{Pt}(\mathbf{1 0})
\end{aligned}
$$

\section{Scheme 1}

The micro-analysis data are consistent with the proposed molecular formulae. The IR spectra of the ligands showed three strong absorption bands between 1625 and 1647 $\mathrm{cm}^{-1}$, which confirmed imine formation [13-15]. The other strong bands observed around $1595 \mathrm{~cm}^{-1}$ and $1559 \mathrm{~cm}^{-1}$ show the presence of $(\mathrm{C}=\mathrm{N})$ and $(\mathrm{C}=\mathrm{C})$ quinolyl vibrations respectively. Coordination of the ligands to the metal centre was confirmed by lower absorption frequencies between 1618 and $1599 \mathrm{~cm}^{-1}$ compared to their corresponding free ligands [13-15]. The $(\mathrm{C}=\mathrm{N})$ and $(\mathrm{C}=\mathrm{C})$ quinolyl vibrations did not show any significant shift in absorption frequency from their corresponding free imines, confirming their non involvement in coordination. 
In the ${ }^{1} \mathrm{H}$ NMR spectra of the ligands, the signal for the imine proton was obscured by the aromatic signals. The quinolyl protons appeared as doublets or triplets between 8.79 and $8.13 \mathrm{ppm}$ due to vicinal proton-proton coupling. In the ${ }^{13} \mathrm{C} \mathrm{NMR}$ analysis, the characteristic signals for the imine carbons appeared at around 163.00 ppm [13-15]. In the NMR spectra of the complexes, the signals generally shifted downfield with respect to their position in the free ligand due to coordination of the ligand.

\subsection{Single crystal $X$-ray diffraction studies}

The molecular structures of some of the complexes were confirmed by X-ray crystallography. Crystallographic data and refinement parameters are summarized in Table 1, while selected bond lengths and bond angles are summarized in Table 2. The molecular structures are shown in Fig. 1 and 2 respectively.

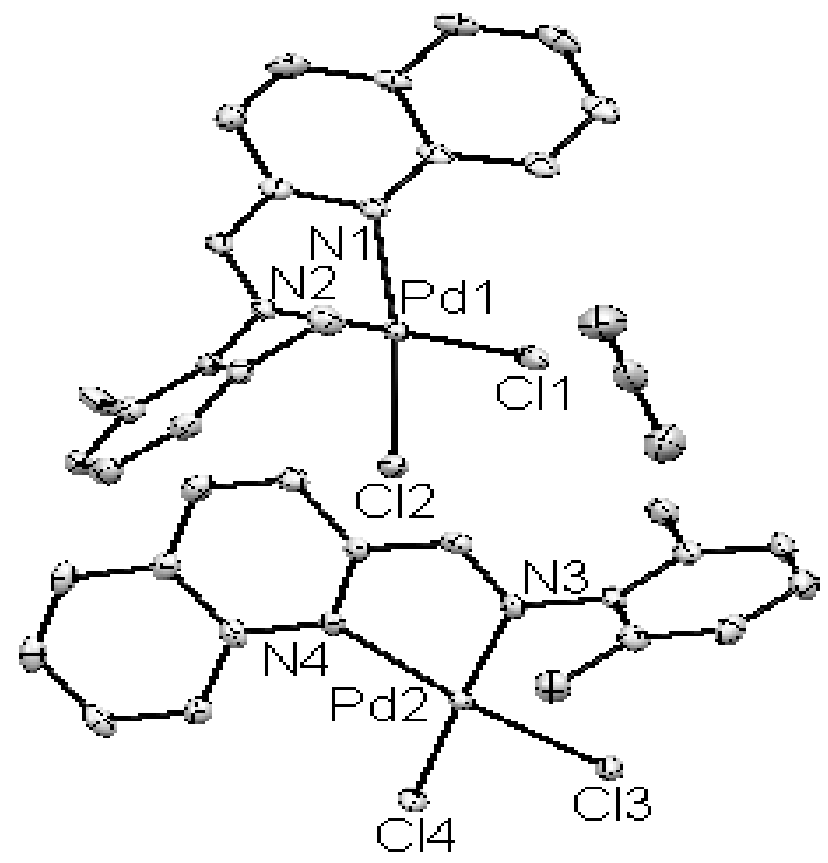

Fig. 1. X-ray crystal structure of complex 3.

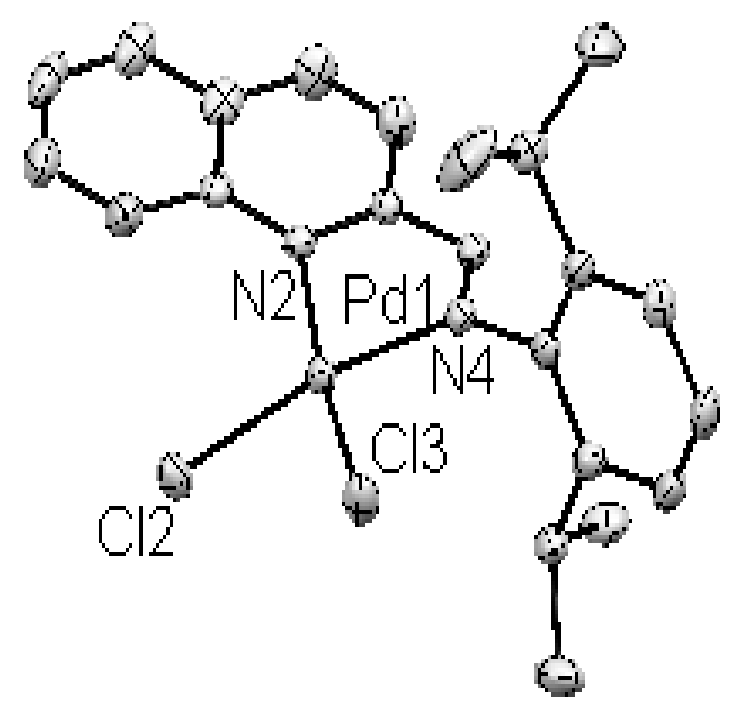


Fig. 2. X-ray crystal structure of complex $\mathbf{5}$.

Table 1: Crystallographic data and refinement for complexes $\mathbf{3}$ and $\mathbf{5}$

\begin{tabular}{|c|c|c|}
\hline Crystallographic data & 3 & 5 \\
\hline $\begin{array}{l}\text { Empirical formula } \\
\text { Formula weight } \\
\text { Temperature }(\mathrm{K}) \\
\text { Crystal system } \\
\text { Space group } \\
\text { Unit cell dimensions } \\
a(\AA) \\
b(\AA) \\
c(\AA) \\
\beta\left({ }^{\circ}\right) \\
\mathrm{V}\left(\AA^{\circ}\right) \\
\mathrm{Z} \\
\mathrm{D}_{\text {cal }}\left(\mathrm{Mgm}^{-3}\right) \\
\mathrm{F}(\text { ooo }) \\
\text { Absorption coefficient (mm } \\
1) \\
\text { Crystal size (mm3) } \\
\text { Number of data collected } \\
\text { Number of parameters } \\
\text { refined } \\
\mathrm{R}\left[\left(F^{2}>2 \sigma\left(F^{2}\right)\right]\right. \\
\text { wR }\left(F^{2}\right) \\
\text { Theta range for data } \\
\text { collection } \\
\text { Goodness-of-fit on } \mathrm{F}^{2} \\
\text { Largest diff. peak and hole }\end{array}$ & $\begin{array}{l}2\left(\underline{\mathrm{C}}_{1} 8 \underline{\mathrm{H}_{16}} \underline{\mathrm{Cl}_{2}} \underline{\mathrm{N}_{2}} \underline{\mathrm{Pd}}\right) \cdot \mathrm{C}_{2} \mathrm{H}_{3} \\
\mathrm{~N} 16.31 \\
100 \\
\text { triclinic } \\
P_{-1} \\
8.0349(5) \\
13.5623(8) \\
17.5006(10) \\
77.043(5) \\
1831.70(19) \\
2 \\
1.661 \\
916 \\
1.31 \\
0.3 \times 0.3 \times 0.3 \\
7435 \\
447 \\
0.036 \\
0.091 \\
2.8 \text { to } 26.4^{\circ} \\
1.08 \\
0.67 \text { and }-1.08 \text { e. } \AA^{-3}\end{array}$ & $\begin{array}{l}\underline{\mathrm{C}}_{22} \underline{\mathrm{H}}_{2} 4 \underline{\mathrm{C}}_{2} \underline{\mathrm{N}_{2}} \underline{\mathrm{Pd}} \\
492.72 \\
100 \\
\text { monoclinic } \\
P_{2} / \mathrm{c} \\
\\
11.4731(6) \\
13.0007(8) \\
14.8263(8) \\
106.356(6) \\
2122.0(2) \\
4 \\
1.542 \\
1000 \\
1.14 \\
0.3 \times 0.2 \times 0.2 \\
4344 \\
248 \\
0.043 \\
0.089 \\
2.9 \text { to } 26.3^{\circ} \\
1.09 \\
0.81 \text { and }-0.82 \text { e. } \AA^{-3}\end{array}$ \\
\hline
\end{tabular}


Table 2: Selected bond lengths and bond angles for compounds 3 and 5

\begin{tabular}{|c|c|c|c|c|}
\hline Compound & \multicolumn{2}{|c|}{ Bond length $(\AA)$} & \multicolumn{2}{|c|}{ Bond angle $\left({ }^{\circ}\right)$} \\
\hline 3 & $\begin{array}{l}\mathrm{Pd}(1)-\mathrm{N}(2) \\
\mathrm{Pd}(1)-\mathrm{N}(1) \\
\operatorname{Pd}(1)-\mathrm{Cl}(2) \\
2.2788(9) \\
\operatorname{Pd}(1)-\mathrm{Cl}(1) \\
\\
\mathrm{Pd}(2)-\mathrm{N}(3) \\
\operatorname{Pd}(2)-\mathrm{N}(4) \\
\operatorname{Pd}(2)-\mathrm{Cl}(3) \\
2.2736(8) \\
\operatorname{Pd}(2)-\mathrm{Cl}(4) \\
2.2956(9)\end{array}$ & $\begin{array}{l}2.020(2) \\
2.074(3) \\
2.2941(8) \\
2.014(3) \\
2.110(3)\end{array}$ & $\begin{array}{l}\mathrm{N}(2)-\mathrm{Pd}(1)-\mathrm{N}(1) \\
80.32(11) \\
\mathrm{Cl}(2)-\mathrm{Pd}(1)-\mathrm{Cl}(1) \\
88.75(3) \\
\mathrm{N}(1)-\mathrm{Pd}(1)-\mathrm{Cl}(1) \\
\mathrm{N}(2)-\mathrm{Pd}(1)-\mathrm{Cl}(2) \\
91.94(8) \\
\\
\mathrm{N}(4)-\mathrm{Pd}(2)-\mathrm{N}(3) \\
80.23(11) \\
\mathrm{Cl}(4)-\mathrm{Pd}(2)-\mathrm{Cl}(3) \\
87.53(3) \\
\mathrm{N}(3)-\mathrm{Pd}(2)-\mathrm{Cl}(3) \\
90.81(8) \\
\mathrm{N}(4)-\mathrm{Pd}(2)-\mathrm{Cl}(4) \\
101.50(8)\end{array}$ & $98.36(7)$ \\
\hline 5 & $\begin{array}{l}\mathrm{Pd}(1)-\mathrm{N}(4) \\
\operatorname{Pd}(1)-\mathrm{N}(2) \\
\operatorname{Pd}(1)-\mathrm{Cl}(3) \\
2.2769(10) \\
\operatorname{Pd}(1)-\mathrm{Cl}(2) \\
2.3081(10)\end{array}$ & $\begin{array}{l}2.026(3) \\
2.098(3)\end{array}$ & $\begin{array}{l}\mathrm{N}(4)-\mathrm{Pd}(1)-\mathrm{N}(2) \\
80.45(12) \\
\mathrm{Cl}(3)-\mathrm{Pd}(1)-\mathrm{Cl}(2) \\
88.13(14) \\
\mathrm{N}(2)-\mathrm{Pd}(1)-\mathrm{Cl}(2) \\
99.99(9) \\
\mathrm{N}(4)-\mathrm{Pd}(1)-\mathrm{Cl}(3) \\
92.69(9)\end{array}$ & \\
\hline
\end{tabular}

Complex 3 crystallizes in the triclinic space group $P$-1, with two structurally identical molecules $(A$ and $B)$ in the asymmetric unit (rms deviation of $0.173 \AA$ when fitting inverted molecule $B$ on molecule A), while 5 crystallizes in the monoclinic space group $P 2_{1} / c$. In the structures, $\pi-\pi$ interactions between quinoline rings link two molecules into centro-symmetric dimers. The palladium atom is four coordinated by two chloride anions and two nitrogen atoms of the bidentate ligand, generating a distorted square planar coordination geometry around the palladium metal centre. The bond angles around the palladium metal atom of $\mathrm{N}(2)-\mathrm{Pd}(1)-\mathrm{N}(1)$ and $\mathrm{Cl}(2)-$ $\mathrm{Pd}(1)-\mathrm{Cl}(1)$ : $80.32(11)^{\circ}$ and $88.75(3)^{\circ}$ for molecule $\mathrm{A}$ in 3 and $80.45(12)^{\circ}$ and $88.13(14)^{\circ}$ in 5 showed significant deviations from $90^{\circ}$, which confirms the distortion in the square planar geometry. These bond angles are in agreement with those of closely related compounds $[11,13,14]$. The $\mathrm{Pd}(1)-\mathrm{C} 1(1)$ and $\mathrm{Pd}(1)-\mathrm{C} 1(2)$ bond lengths of 2.2941(8) $\AA$ and 2.2788(9) $\AA$ for molecule $A$ in 3 and 2.2769(10) $\AA$ and 
2.3081(10) $\AA$ in 5 are in good agreement with the average $\mathrm{Pd}-\mathrm{Cl}$ bond distance of 2.298(15) $\AA$ for known palladium complexes [16,17]. There is detectable transinfluence taking place for the chloride ligands since the bond distance $\mathrm{Pd}(1)-\mathrm{Cl}(1)$ is slightly longer than $\mathrm{Pd}(1)-\mathrm{Cl}(2)$, thus reflecting the stronger trans- influence of the quinolyl group compared to the secondary amine [18].

\subsection{Cytotoxicity studies}

The aim of this study was to evaluate imino-quinolyl palladium(II) and platinum(II) complexes as possible antitumor agents. The complexes were derived from chelating, bidentate quinolyl imine ligands containing substituted aniline, thereby making them sterically congested. As indicated earlier, steric congestion protects the central metal atom from deactivation, thereby permitting high selectivity to DNA binding [6], while chelating, bidentate ligands prevent trans-labilization and undesired displacement of the ligands [4].

The free imino-quinolyl ligand $\mathbf{L 1}$ and some palladium(II) complexes and platinum(II) complexes were evaluated for their potential to exert cytotoxicity on highly invasive human breast (MCF-7) and human colon (HT-29) tumor cells using 3-(4,5-dimethyl-2-thiazolyl)-2,5-diphenyl-2H-tetrazolium bromide (MTT) assay with minor modifications [19-21]. The compounds were first solubilized in dimethylsulfoxide (DMSO). Cell growth inhibition results, expressed as concentration of the complex required to inhibit tumor cell growth by $50 \%\left(\mathrm{IC}_{50}\right)$ are summarized in Table 3. Cytotoxicity of cisplatin was evaluated under the same experimental conditions for comparison. The imino-quinolyl ligand $\mathbf{L 1}$ was also evaluated to assess whether free imino-quinolyl ligands could exert cytotoxicity on cancer cells. However, the ligand did not return any appreciable activity $\left(\mathrm{IC}_{5}\right.$ o $>100$ $\mu \mathrm{M})$. The imino-quinolyl palladium(II) and platinum(II) complexes exhibited growth inhibitory activities against MCF-7 and HT-29 cancer cell lines which were superior to the reference compound cisplatin, which returned $\mathrm{IC}_{50}$ values around $100 \mu \mathrm{M}$. The highest cytotoxic activities were pronounced in complexes 5 and $\mathbf{1 0}\left(\mathrm{IC}_{5} \mathrm{o} 46.01\right.$ and $39.90 \mu \mathrm{M}$ ), which were approximately two times more active than cisplatin against the two examined cancer cell lines. These complexes contain two iso-propyl groups substituted at ortho-positions on the phenyl ring, making them more sterically demanding. The trend confirms the importance of steric congestion in preventing axial approach to the coordinated metal atom and permitting high selectivity to DNA binding [6]. However, there was insignificant difference in activities between complexes containing two iso-propyl groups and those with two methyl groups on the phenyl ring. 
Table 3: Cytotoxic activities for the free ligand and complexes tested against MCF-7 and HT-29 cancer cell lines

\begin{tabular}{|c|c|c|}
\hline \multicolumn{3}{|c|}{ I $_{\mathbf{5 0}}(\boldsymbol{\mu M})$} \\
\hline Compound & MCF-7 & HT-29 \\
\hline Lalladium(II) & $>100$ & $>100$ \\
complexes & $63.87 \pm 0.23$ & $58.96 \pm 2.98$ \\
$\mathbf{1}$ & $62.76 \pm 2.36$ & $57.88 \pm 1.85$ \\
$\mathbf{2}$ & $47.58 \pm 1.66$ & $43.89 \pm 0.74$ \\
$\mathbf{3}$ & $46.01 \pm 0.95$ & $42.79 \pm 1.69$ \\
$\mathbf{5}$ & & \\
\hline Platinum(II) & & \\
complexes & $59.86 \pm 2.38$ & $54.75 \pm 0.81$ \\
$\mathbf{6}$ & $57.59 \pm 2.45$ & $53.84 \pm 2.11$ \\
7 & $45.99 \pm 0.99$ & $41.92 \pm 1.33$ \\
$\mathbf{8}$ & $44.90 \pm 1.86$ & $39.90 \pm 0.92$ \\
$\mathbf{1 0}$ & & 100 \\
\hline Cisplatin & 100 & \\
\hline
\end{tabular}

$I C_{50}$ is the concentration of the complex required to inhibit cell growth by $50 \%$ Data are presented otherwise specified as mean $\pm S D$ of $I C_{50}(\mu \mathrm{g} / \mathrm{ml})$ from 3 independent experiments

All the complexes generally exhibited higher cytotoxic activities against human colon (HT-29) cell line ( $\mathrm{IC}_{5}$ o 39.90-58.96 $\mu \mathrm{M}$ ) compared to the human breast (MCF-7) cell line. Furthermore, imino-quinolyl platinum(II) complexes showed slightly superior cytotoxic activities compared to their palladium(II) counterparts across the examined cancer cell lines, probably due to the higher lability of palladium(II) compared to their platinum(II) analogues, which makes them to dissociate readily in solution, leading to very reactive species that are unable to reach their pharmacological targets [22-23]. The complexes are also square planar with metal chloride bonds in cis-position, and when considering the proposed mechanism of action of cisplatin [24,25], it is reasonable to suggest that cytotoxicity of these iminoquinolyl complexes is derived from DNA binding. Our group has recently reported cytotoxic activities of complex 4 showing similar trend [10].

\section{4.o Conclusions}

We have successfully synthesized and fully characterized sterically congested palladium(II) and platinum(II) complexes derived from chelating imino-quinolyl ligands. The complexes were evaluated in vitro for their potential to exert cytotoxicity on human breast (MCF-7) and human colon (HT-29) cancer cell lines. The free ligand did not return any appreciable activity. However, the complexes exhibited growth inhibitory activities that were even better than cisplatin. 


\section{Acknowledgements}

The authors thank University of the Western Cape, National Research Foundation and University of Leuven's International Admissions and Mobility Office (WMM) for financial support. The authors also thank the Hercules Foundation for supporting the purchase of the diffractometer through project AKUL/o9/o035.

\section{Supplementary material}

CCDC no. 908050 and 908051 contain the supplementary crystallographic data for compound $\mathbf{3}$ and $\mathbf{5}$ respectively. Copies of this information may be obtained free of charge from The Director, CCDC, 12 Union Road, Cambridge, CB2 1EZ, UK (fax: +44-1223-336033; e-mail: $\quad$ deposit@ccdc.cam.ac.uk or ww: http://www.ccdc.cam.ac.uk). 


\section{References}

[1] a) A.S. Abu-Surrah, K.A. Abu Safieh, I.M. Ahmad, M.Y.Abdalla, M.T. Ayoub, A.K. Qaroush, A.M. Abu-Mahtheieh, Eur. J. Med. Chem. 45 (2010) 471

b) E. Budzisz, M. Miernicka, I.P. Lorenz, P. Mayer, U. Krajewska, M. Rozalski, Polyhedron. 28 (2009) 637

c) F.K. Keter, S.O. Ojwach, O.A. Oyetunji, I.A. Guzei, J. Darkwa, Inorg. Chim. Acta 362 (2009) 2595

d) M. Miernicka, A. Szulawska, M. Czyz, I.P. Lorenz, P. Mayer, B. Karwowski, E. Budzisz, J. Inorg. Biochem. 102 (2008) 157

e) F.K. Keter, S. Kanyanda, S.S.L. Lantagaye, J. Darwa, D.J.G. Rees, M. Meyer, Cancer Chemother. Pharmacol. 63 (2008) 127

[2] S.H. van Rijt, P.J. Sadler, Drug. Discov. Today. 14 (2009) 1089

[3] a) M. van Beusichem, N. Farrell, Inorg. Chem. 31 (1992) 634

b) J. Holford, F. Raynaud, B.A. Murrer, K. Grimaldi, J.A. Hartley, M. Abrams, L.R. Kelland, Anti-Cancer Drug Des. 13 (1998) 1

c) P. Kopf-Maier, H. Kopf, Chem. Rev. 87 (1987) 1137

d) M.J. Clarke, F. Zhu, D.R. Frasca, Chem. Rev. 99 (1999) 2511

[4] E. Wong, M. Giandomenico, Chem. Rev. 99 (1999) 2451

[5] A.S. Abu-Surrah, H.H. Al-Sadoni, M.Y. Abdalla, Cancer Therapy. 6 (2008) 1

[6] a) A.C.G. Hotze, Y. Chen, T.W. Hambley, S. Parsons, N.A. Kratochwil, J.A. Parkison,.P. Munk, P.J. Sadler, Eur. J. Inorg. Chem. (2002) 1035

b) M.L. Conrad, J.E. Enman, S.J. Scales, H. Zhang, C.M. Vogels, M.T. Saleh, A. Decken, S.A. Westcott, Inorg. Chim. Acta. 358 (2005) 63

c) S.J. Scales, H. Zhang, P.A. Chapman, C.P. McRory, E.J. Derah, C.M. Vogels, M.T. Saleh, A. Decken, S.A. Westcott, Polyhedron. 23 (2004) 2169

[7] J. Wiedermann, K. Mereiter, K. Kirchner, J. Mol. Catal. A: Chem. 257 (2006) 67

[8] G. M. Sheldrick, Acta Cryst. A64 (2008) 112

[9] O.V. Dolomanov, L.J. Bourhis, R.J. Gildea, J.A.K. Howard, H. Puschmann, J. Appl. Cryst. 42 (2009) 339

[10] W.M. Motswainyana, M.O. Onani, J. Jacobs, L. van Meervelt, Acta Cryst. C68 (2012) $\mathrm{m} 356$

[11] W.M. Motswainyana, M.O. Onani, A.M. Madiehe, Acta Cryst. E68 (2012) m380

[12] A. Koppl, H.G. Alt, J. Mol. Catal. A: Chem. 154 (2000) 45

[13] a) W.M. Motswainyana, M.O. Onani, A.M. Madiehe, Polyhedron. 41 (2012) 44

b) W.M. Motswainyana, S.O. Ojwach, M.O. Onani, E.I. Iwuoha, J. Darkwa, Polyhedron. 30 (2011) 2574

[14] W. Zhang, W-H. Sun, B. Wu, S. Zhang, H. Ma, Y. Li, J. Cheng, P. Hao, J. Organomet. Chem. 691 (2006) 4759

[15] J.D.A. Pelletier, J. Fawcett, K. Singh, G.A. Solan, J. Organomet. Chem. 693 (2008) 2723

[16] W. Chen, C. Xi, Y. Wu, J. Organomet. Chem. 692 (2007) 4381

[17] F.H. Allen, Acta Crystallogr. B58 (2002) 380

[18] S. Doherty, J.G. Knight, T.H. Scanlam, M.R.J. Elsegood, W Clegg, J. Organomet. Chem. 650 (2002) 231 
[19] Z. Petrovski, M.R.P. Norton de Matos, S.S. Braga, C.C.L. Pereira, M.L. Matos, I.S. Goncalves, M. Pillinger, P.M. Alves, C.C. Romao, J. Organomet. Chem. 693 (2008) 675

[20] T. Mosmann, J. Immunol. Methods. 65 (1983) 55

[21] F.M. Freimoser, C.A. Jacob, M. Aebi, U. Tuor, Appl. Environ. Microbiol. 65 (1999) 3727

[22] A.S. Abu-Surrah, M. Kettunen, Curr. Med. Chem. 13 (2006) 1337

[23] G. Zhao, H. Lin, P. Yu, H. Sun, S. Zhu, X. Su, Y. Chen, J. Inorg. Biochem. 73 (1999) 145

[24] M.A. Fuertes, C. Alonso, J.M. Perez, Chem. Rev. 103 (2003) 645

[25] Y. Jung, S.J. Lippard, Chem. Rev 107 (2007) 1387 